\title{
Intermittent cold-blood vs. warm-blood cardioplegia - a comparative study on myocardial acidosis during coronary bypass surgery
}

\author{
A Borowski', E Godehardt, G Paprotny, M Kurt \\ From 23rd World Congress of the World Society of Cardio-Thoracic Surgeons \\ Split, Croatia. 12-15 September 2013
}

The aim of the study was to assess the impact of the intermittent cold-blood cardioplegia (ICBC) on myocardial acidosis in comparison to the warm-blood cardioplegic administration (IWBC) in patients undergoing coronary bypass surgery.

In 15 patients undergoing elective bypass surgery with ICBC for myocardial protection, metabolic changes of global ischemia indicators with lactate and $\mathrm{pH}$ values, measured simultaneously in the arterial and coronary sinus blood, were analyzed and compared with those observed when warm-blood method was used. For comparison, the analysis of variance with repeated measurements including tests for a cross-over effect of group and time was used.

In patients with ICBC compared to IWBC, the lactate production as well as degree of acidosis were generally lower with a significant group effect for both, lactate and $\mathrm{pH}$ values measured at the end of reperfusions. Our results suggest that ICBC has an inhibiting effect on potentially progressive myocardial acidosis during cross clamp period.

Submit your next manuscript to BioMed Central and take full advantage of:

- Convenient online submission

- Thorough peer review

- No space constraints or color figure charges

- Immediate publication on acceptance

- Inclusion in PubMed, CAS, Scopus and Google Scholar

- Research which is freely available for redistribution

○ 2013 Borowski et al; licensee BioMed Central Ltd. This is an Open Access article distributed under the terms of the Creative Commons Attribution License (http://creativecommons.org/licenses/by/2.0), which permits unrestricted use, distribution, and reproduction in any medium, provided the original work is properly cited. 